\title{
Pengaruh Penggunaan Modul Biokimia pada Mahasiswa Pendidikan Biologi STKIP-PGRI Lubuklinggau
}

\author{
Eka Lokaria
}

STKIP-PGRI Lubuklinggau

surat elektronik: ekalokaria23@yahoo.com

\begin{abstract}
ABSTRAK
Peranan dan penggunaan sumber belajar secara terencana dan terprogram akan berpengaruh pada pencapaian tujuan pembelajaran yang ditargetkan. Salah satu sumber belajar yakni modul. Modul merupakan paket belajar mandiri yang meliputi serangkaian pengalaman belajar yang direncanakan dan dirancang secara sistematis untuk membantu peserta didik mencapai tujuan belajar. Tujuan penelitin ini untuk mengetahui: (1) Hasil belajar mahasiswa setelah mengikuti pembelajaran Biokimia menggunakan modul. (2) Aktivitas mahasiswa pada proses pembelajaran Biokimia menggunakan modul. Populasi sebagai sampel dalam penelitian ini adalah mahasiwa pendidikan Biologi semester III angkatan 2014 STKIP-PGRI Lubuklinggau. Pengumpulan data dilakukan dengan metode tes dan observasi. Data interval dianalisis dengan SPSS versi 10.05 dengan non parametik berupa Mann Whitney. Dari output Rank, dapat kita lihat bahwa nilai mean untuk siswa eksperimen lebih besar daripada nilai mean siswa kontrol $(15,05>5,95)$ sehingga dapat disimpulkan bahwa hasil belajar Biokimia setelah menggunakan modul meningkat. Aktivitas mahasiswa saat mengikuti pembelajaran menggunakan modul baik.
\end{abstract}

Kata kunci: Pengaruh, Modul, Hasil Belajar dan Biokimia

\section{Pendahuluan}

Dalam rangka menyiapkan lulusan pendidikan memasuki era globalisasi yang penuh tantangan diperlukan pembelajaran yang dirancang berdasarkan kebutuhan nyata di lapangan. Salah satunya yakni menemukan cara yang terbaik untuk menyampaikan berbagai konsep yang diajarkan, sehingga mahasiswa dapat menggunakan dan mengingat lebih lama konsep tersebut serta mata kuliah Biokimia dipahami sebagai bagian yang saling berhubungan dan membentuk suatu pemahaman yang utuh.

Proses pembelajaran pada hakekatnya merupakan interaksi antara peserta didik dengan obyek yang dipelajari. Oleh karena itu peranan sumber dan media belajar sangat diperlukan dalam proses pembelajaran Biokimia guna pencapaian pemahaman yang utuh. Peranan dan penggunaan sumber belajar secara terencana dan terprogram akan berpengaruh pada pencapaian tujuan pembelajaran yang ditargetkan. Salah satu sumber belajar yakni modul. Modul merupakan paket belajar mandiri yang meliputi serangkaian pengalaman belajar yang direncanakan dan dirancang secara sistematis untuk membantu peserta didik mencapai tujuan belajar. (Mulyasa, 2002).

\section{Metode Penelitian}

Penelitian ini merupakan penelitian eksperimen murni yang memiliki ciri khas kelompok yang dikenal dengan kelompok eksperimental. Menurut Arikunto (2010) penelitian eksperiment adalah suatu cara untuk mencari hubungan sebab akibat antara dua faktor yang sengaja ditimbulkan oleh peneliti dengan mengurangi atau menyisihan faktor-faktor lain yang menggangu. Pada penelitian ini digunakan Modul dan instrumen untuk mengukur hasil belajar Biokimia yang dikembangkan dalam bentuk tes.

\section{Prosedur Penelitian}

Penelitian ini dilakukan di STKIP-PGRI Lubuklinggau, untuk mahasiswa pendidikan Biologi semester III angkatan 20I4. Penelitian ini dibagi dalam dua kelompok yakni kelompok eksperiment dan kelompok kontrol. Kelompok eksperiment diberikan bahan ajar dalam bentuk Modul sedangkan kelompok kontrol tidak diberikan Modul. Proses pembelajarannya diajarkan dengan metode kontekstual. berikut: 
1. Studi pustaka tentang modul dan hasil belajar, dalam penyusunan bahan ajar dalam bentuk modul, terlebih dahulu dicari literatur mengenai modul. Untuk mengukur manfaat modul dalam pembelajaran dianalisis melalui hasil belajar.

2. Menyusun draf modul dan instrumen penelitian. Pada umumnya sebuah modul terdiri atas komponen-komponen sebagai berikut: a) Lembar kegiatan peserta didik, b) Lembar kerja, c) Kunci lembar kerja, d) Lembar soal. e) Lembar jawaban, dan f) Kunci jawaban

3. Validasi atau pertimbangan ahli tentang modul dan instrument penelitian (Ahli Materi, Pembelajaran dan Praktisi)

4. Revisi modul dan instrument penelitian

5. Uji coba terbatas

6. Revisi modul dan instrument penelitian

7. Uji coba dalam kelompok yang lebih luas

8. Revisi modul dan instrument penelitian

9. Menyusun perangkat pembelajaran (silabus, RPP, skenario pembelajaran) dan digunakan pada kelompok eksperimen dan kontrol

10. Memberikan tes hasil belajar

11. Análisis data dan diperoleh modul yang efektif untuk meningkatkan hasil belajar (Sugiono, 2010).

\section{Desain penelitian}

Desain penelitian yang akan digunakan dalam penelitian ini dipilih secara random acak, dapat digambarkan dengan pola sebagai berikut:

\begin{tabular}{cccc}
\hline Kelas & Perlakuan & Pre-Test & Post-Tes \\
\hline Eksperimen & $\mathrm{O}_{1}$ & $\mathrm{X}$ & $\mathrm{O}_{2}$ \\
Kontrol & $\mathrm{O}_{1}$ & - & $\mathrm{O}_{2}$ \\
\hline
\end{tabular}

Instrumen Penelitian

Instrumen berupa tes hasil belajar matakuliah Biokimia. Instrumen tersebut perlu diketahui validitas dan realibilitasnya. Validitas merupakan suatu instrument ukuran yang menunjukkan tingkat kevalitan dan kesahihan suatu instrumen. Realibilitas instrumen adalah ukuran yang menunjukkan pada suatu pengertian bahwa suatu instrumen cukup dapat dipercaya untuk digunakan sebagai alat pengumpul data karena instrumen tersebut baik (Arikunto, 2010).

Teknik pengumpulan data diperoleh dengan meggunakan tes hasil belajar yang berbentuk hubungan sebab akibat. Teknik análisis data menggunakan teknik análisis kuantitatif. Bila data berdistribusi normal maka digunakan uji statistik parametrik, jika tidak berdistribusi normal digunakan uji statistik nonparametrik.

Persyaratan penggunaan uji pada statistik parametrik sebagai berikut:

I. Sampel diambil secara random (acak)

2. Data berdistribusi normal

3. Kedua kelompok homogen

\section{Uji hipotesis}

Data yang terkumpul selanjutnya dianalisis. Untuk menganalisis data digunakan teknik sebagai berikut: Pertama untuk menganalisis data hasil belajar Biokimia digunakan dari hasil post-test pada setiap kelompok eksperimen dengan kelompok kontrol. Data interval dianalisis dengan SPSS versi 10.05 dengan non parametik berupa mann whitney.

Hipotesis statistik yang diuji pada penelitian ini adalah:

Tidak terdapat perbedaan hasil belajar

Ho Biokimia mahasiswa yang diajarkan menggunakan modul dan yang tidak menggunakan modul

Terdapat perbedaan hasil belajar Biokimia

$\mathrm{Ha}$ mahasiswa yang diajarkan menggunakan modul dan yang tidak menggunakan modul

Pengambilan keputusan:

Jika nilai signifikan hitung $<0,05$ maka HO ditolak.

Jika nilai signifikan hitung $>0,05$ maka $\mathrm{HO}$ diterima.

Tingkat signifikansi $(\alpha)$ adalah 5\%

\section{Hasil dan Pembahasan}

Tabel I. Hasil pretest-posttest

\begin{tabular}{ccccc}
\hline \multirow{2}{*}{ No. } & \multicolumn{2}{c}{ Kelas Eksperimen } & \multicolumn{2}{c}{ Kelas Kontrol } \\
\cline { 2 - 5 } & Pre-test & Post-test & Pre-test & Post-test \\
\hline 1 & 50 & 80 & 50 & 70 \\
2 & 70 & 100 & 30 & 60 \\
3 & 60 & 90 & 60 & 80 \\
4 & 60 & 100 & 50 & 70 \\
5 & 40 & 80 & 30 & 70 \\
6 & 50 & 100 & 50 & 80 \\
7 & 60 & 100 & 40 & 60 \\
8 & 40 & 80 & 40 & 80 \\
9 & 60 & 90 & 50 & 70 \\
10 & 30 & 90 & 30 & 60 \\
\hline
\end{tabular}

Dari hasil pre-test dan post-test yang diperoleh nilai rata-rata pre-test untuk kelompok eksperimen adalah 52 dan rata-rata post-test kelompok eksperimen adalah 91. Untuk kelompok kontrol rata-rata pre-test adalah 43 dan hasil rata-rata post tes adalah 70. Dari hasil tersebut jelas terlihat bahwa hasil belajar post-test lebih tinggi dari nilai pre-test artinya kemampuan awal siswa sebelum pembelajaran akan bertambah setelah diberikan pembelajaran. Dari hasil post-test yang diperoleh terlihat bahwa nilai siswa pada kelas eksperimen dengan perlakuan pembelajaran menggunakan modul lebih tinggi dibandingkan dengan kelas kontrol yang tidak menggunakan modul. Untuk kelompok eksperimen nilai terendah adalah 80 dan nilai tertinggi adalah 
100. Sedangkan untuk kelompok kontrol nilai terendah adalah 60 dan nilai tertinggi adalah 80 .

Mengingat banyak data penelitian untuk kelompok eksperimen dan kelompok kontrol masing-masing sebanyak 10 siswa maka data berdistribusi tidak normal. Menurut Supranto (2001) Bila banyaknya data kurang dari 30 maka data berdistribusi tidak normal.

Data di atas kemudian dianalisis dengan menggunakan analisis non-parametrik yaitu Mann Whitney. Metode statistik non-parametrik dipakai apabila peneliti tidak mengetahui karakteristik kelompok yang menjadi sumber sampelnya, selain itu statistik non-parametrik digunakan apabila sampelnya kecil sehingga distribusi penarikan sampel dari statistik tidak mendekati distibusi normal. Uji Mann Whitney digunakan untuk mengetahui ada tidaknya perbedaan dari dua himpunan data yang berasal dari sampel yang independen. Uji Mann Whitney merupakan uji alternatif dari uji $\mathrm{T}$. Uji Mann Withney tidak memerlukan asumsi data berdistribusi normal namun hanya mengasumsikan bahwa populasi-polulasi tersebut memiliki bentuk yang sama. Kelebihan uji ini dibandingkan uji $\mathrm{T}$ adalah uji ini dapat digunakan pada data ordinari atau data peringkat. $U_{j i}$ ini dapat disebut sebagai uji U. Karena sampel yang digunakan pada penelitian ini sedikit atau dapat disebut data tidak berdistibusi normal maka analisis yang digunakan pada penelitian ini adalah analisis non-parametrik Mann Whitney (Supranto, J. 200I). Hasil analisis dapat dilihat pada table 2 dan tael 3 dibawah ini:

Tabel 2. Hasil Analisis Mann Whitney Ranks

\begin{tabular}{|c|l|l|l|}
\hline Faktor & N & $\begin{array}{l}\text { Mean } \\
\text { Rank }\end{array}$ & $\begin{array}{l}\text { Sum of } \\
\text { Ranks }\end{array}$ \\
\hline skor Kontrol & I0 & 5.95 & 59.50 \\
eksperimen & I0 & I5.05 & I50.50 \\
Total & 20 & & \\
\hline
\end{tabular}

Tabel 3.Test Statistics ${ }^{\mathrm{b}}$

\begin{tabular}{|l|l|}
\hline & skor \\
\hline Mann-Whitney U & 4.500 \\
Wilcoxon W & 59.500 \\
Z & -3.524 \\
Asymp. Sig. (2-tailed) & .000 \\
Exact Sig. [2*(I-tailed Sig.)] & $.000 \mathrm{a}$ \\
\hline
\end{tabular}

a. Not corrected for ties.

b. Grouping Variable: faktor
Dari output Rank, dapat kita lihat bahwa nilai mean untuk siswa eksperimen lebih besar daripada nilai mean siswa kontrol (I5,05 > 5,95). Nilai uji Mann-Whitney U, dapat kita lihat pada output "Test Statisticb" nilai sig.2-tailed (signifikansi untuk uji dua sisi) adalah 0,000 atau probabilitas di atas $0.05(0.000<0.05)$. Karena itu Ho ditolak dan $\mathrm{Ha}$ diterima yang artinya terdapat perbedaan antara siswa yang belajar dengan menggunakan Modul dan siswa yang tidak menggunakan Modul. Adanya perbedaan hasil belajar yang diperoleh antara kelas kontrol dan eksperimen menunjukkan bahwa penggunaan Modul benar-benar mampu meningkatkan hasil belajar. Mahasiswa secara sistematis diarahkan lebih mandiri, aktif dan kreatif, demokratis, berpikir logis, dan berwawasan luas. Hal ini berdampak positif terhadap pembelajaran terbukti dari hasil pembelajaran yang diperoleh.

Berdasarkan penelitian, diperoleh data tentang keaktifan mahasiswa. Selanjutnya untuk kepentingan interpretasi kategori penilaian keaktifan mahasiswa Pendidikan Biologi STKIP-PGRI Lubuklinggau dilakukan analisis data, yang hasilnya seperti pada table 4 di bawah ini:

Tabel 4. Observasi Keaktifan Mahasiswa Kelas Eksperimen

\begin{tabular}{ll}
\hline I Indikator & Skor \\
o. & \\
\hline I Kegiatan Pendahuluan & 9 \\
2 Kegiatan Inti & I5 \\
3 Penutup & I I \\
\hline Jumlah skor & 35 \\
\hline Kategori Penilaian & baik \\
\hline
\end{tabular}

Berdasarkan tabel 4, maka hasil penelitian tentang keaktifan siswa kelas eksperimen menunjukkan jumlah skor sebesar 35, sehingga hasil observasi keaktifan siswa kelas eksperimen mahasiswa Pendidikan Biologi semester III STKIP-PGRI Lubuklinggau berkategori penilaian baik.

Berdasarkan penelitian, diperoleh data tentang keaktifan mahasiswa. Selanjutnya untuk kepentingan interpretasi kategori penilaian keaktifan mahasiswa kelas kontrol dilakukan analisis data, yang hasilnya seperti pada table 5 di bawah ini:

Tabel 5. Observasi Keaktifan Mahasiswa Kelas Kontrol

\begin{tabular}{cll}
\hline No. & Indikator & Skor \\
\hline I & Kegiatan Pendahuluan & 9 \\
2 & Kegiatan Inti & I I \\
3 & Penutup & 9 \\
\hline & Jumlah skor & 28 \\
\hline Kategori Penilaian & Cukup \\
\hline
\end{tabular}

Berdasarkan data diatas maka hasil penelitian tentang keaktifan mahasiswa kelas kontrol menunjukkan jumlah skor sebesar 28, sehingga hasil observasi keaktifan mahasiswa kelas kontrol berkategori penilaian cukup. 
Selain itu keefektifan evaluasi yang dilakukan dapat dilihat dari setiap mahasiswa yang dapat mengumpulkan dan menyerahkan lembar jawaban tugas/pertanyaan sesuai jadwal yang ditentukan. Lembar pengamatan dan tabel pengamatan diisi secara lengkap oleh mahasiswa.

\section{Simpulan}

Berdasarkan hasil penelitian hasil belajar mahasiswa setelah mengikuti pembelajaran Biokimia menggunakan modul bahwa nilai mean untuk siswa eksperimen lebih besar daripada nilai mean siswa kontrol 15,05 > 5,95 yang artinya terdapat perbedaan antara siswa yang belajar dengan menggunakan Modul dan siswa yang tidak menggunakan Modul.

Keaktifan mahasiswa Pendidikan Biologi semester III STKIP-PGRI Lubuklinggau kelas eksperimen menunjukkan jumlah skor sebesar 35 dan kelas kontrol 28, sehingga hasil observasi keaktifan siswa kelas eksperimen berkategori baik dan kelas kontol berkatagori cukup.

\section{Daftar Pustaka}

Suharsimi. 2010. Prosedur Penelitian Suatu Pendekatan Praktik. Jakarta: Rineka Cipta.

Mulyasa, E. 2002. Kurikulum Berbasis Kompetensi, Karakteristik, Implementasi, dan Inovasi. Remaja Rosdakarya: Bandung.

Sugiono, 2010 Metodologi Penelitian Pendidikan. Alfabeta : Bandung.

Supranto, J. 200I Statistik untuk Pemimpin Berwawasan Global. Jakarta: Salemba Empat.

Smaldio, Sharon E., Deborah L. Lowter, dan James D. Russel. 20II. Instructional Technology and Media for Learning. Terjamah oleh Arif Rahman. Jakarta: Kencana Prenada Media Group. 